\title{
Kajian Ikonografi dan Fungsi Arca Hindu-Buddha di Pura Agung Batan Bingin Pejeng Kawan
}

\author{
Anak Agung Gede Raka Dewantara*, I Wayan Srijaya, Ida Bagus Sapta Jaya \\ Prodi Arkeologi, Fakultas Ilmu Budaya, Universitas Udayana \\ Email: gungraka42@gmail.com \\ Gianyar, Bali, Indonesia \\ *Corresponding Author
}

\begin{abstract}
Period Hindu-Buddha in Indonesian, Leaving behind a variety of archaeological heights. Research to investigate the definition statue HinduBuddha at Agung Batan Bingin Temple, Pejeng Kawan Village. The purpose of this study is to reconstruct the history of Balinese culture in the past especially its aspect of religment. The writer apply this method for accumulation file like library study, observasion, interview as well as analysis, iconography. The theory used to help analysis is the functional theory. Based on the results of the research Found that there is an iconography mark in the statues of Hindu-Buddha on Agung Batan Bingin Temple. Iconography mark show the variety of jewelry, clothing, art, and posture depiction. Statue Hindu-Buddha on Bingin Temple including to ancient Balinese periodic. Statue Hindu-Buddha on Agung Batan Bingin Temple untill now still being used as an instrument of veneration by the people of Bali performing religious ceremonies, the Balinese people used to call it "Penyungsung Pura". Statue Hindu-Buddha the, believed in society pejeng kawan village as a means of begging for protection, safety, and plants fertility in society Pejeng Kawan Village.
\end{abstract}

\section{Keyword : Statue Hindu-Buddha, Iconography, Ganesha, Bodhisattwa}

\begin{abstract}
Abstrak
Periode Hindu-Buddha di Indonesia menyisakan tinggalan arkeologi yang beragam. Penelitian ini meneliti ciri-ciri ikonografi dan fungsi pada arca Hindu-Buddha di Pura Agung Batan Bingin, Desa Pejeng Kawan, Tampaksiring, Gianyar. Tujuan penelitian ini adalah untuk merekonstruksi sejarah kebudayaan masyarakat Bali pada masa lalu terutama aspek religinya. Penulis menggunakan metode pengumpulan data seperti studi pustaka, observasi dan wawancara serta pengolahan data melalui analisis Kualitatif, analisis ikonografi. Teori yang digunakan untuk membantu analisis adalah teori fungsional. Hasil analisis ditemukan bahwa terdapat ciri-ciri ikonografi pada arca-arca Hindu-Buddha di Pura Agung Batan Bingin. Ciri-ciri ikonografi terlihat pada ragam penggambaran perhiasan, busana, laksana, dan sikap tubuh. Arca Hindu-Buddha di Pura Agung Batan Bingin dapat dimasukan kedalam periodesasi Bali Kuna. Arca HinduBuddha di Pura Agung Batan Bingin tersebut sampai sekarang masih dimanfaatkan sebagai sarana pemujaan oleh penyungsung pura. Arca Hindu-
\end{abstract}


Buddha tersebut dipercaya oleh masyarakat desa Pejeng Kawan sebagai sarana untuk memohon perlindungan, keselamatan, dan kesuburan.

Kata Kunci : Arca Hindu-Buddha, Ikonografi, Ganesha, Bodhisattwa

\section{PENDAHULUAN}

Periode Hindu-Buddha di Indonesia menyisakan tinggalan arkeologi yang beragam dan dapat dikatakan sebagai puncak-puncak kebudayaan Indonesia sehingga sering dikatakan sebagai Periode Klasik (Darma, 2019). Jenis tinggalan arkeologi dari periode ini pada umumnya berasal dari aktivitas keagamaan Hindu-Buddha yang terdiri atas candi, arca, dan sisa-sisa aktivitas ritual lainnya (Anggarini, 2017). Salah satu tinggalan arkeologi yang paling banyak ditemukan adalah arca.

Arca adalah artefak yang berbentuk tiga dimensi. Arca dapat dihasilkan melalui teknik bentukan tangan, pahat, cetak, dan ukir. Bahan yang digunakan dapat berupa batu, kayu, tanah liat atau logam (Purwanto, 2018). Arca dalam bahasa Sansekerta yang berarti perwujudan jasmani seseorang dewa yang dipuja oleh para bhakta, yaitu orang yang berbakti atau memuja (Maulana, 1997). Arca bukan hanya merupakan sebuah karya seni semata, namun arca memiliki peranan yang penting dalam kegiatan peribadatan dan diikat oleh sejumlah ketentuan ketentuan aliran agama yang bersangkutan (Arifin, 2015). Ketentuan-ketentuan tersebut dapat berkaitan dengan cara-cara pelaksanaan pengarcaan maupun dengan pelambangan pengertian tertentu ke dalam bentukbentuk perwujudan tertentu. Oleh sebab itu arca tidak dapat dibuat dengan sembarangan.

Mempelajari arca, dibutuhkan beberapa ilmu bantu, seperti ikonografi, ikonologi, dan ikonometri (Prayudi, 2016). Ilmu bantu tersebut mempunyai peranan dalam menggambarkan identitas dewa, dalam hal ini adalah ciri-ciri pokoknya. Akan tetapi, seringkali ciri pokok tersebut tidak sepenuhnya diikuti oleh seniman arca, sehingga menghasilkan variasi penggambaran (Putra, 2018). Variasi yang terjadi dapat dipengaruhi oleh perbedaan waktu, wilayah, atau sekte-sekte keagamaan yang melatar belakangi keberadaan arca (Maulana, 1997: 1-3). Objek yang dikaji dalam penelitian ini adalah arca HinduBuddha di Pura Agung Batan Bingin Desa Pejeng Kawan, Kecamatan Tampaksiring, Kabupaten Gianyar yang hingga sekarang masih dijaga dan dimanfaatkan untuk kegiatan yang bersifat religius oleh penyungsung tersebut.

Di Pura Agung Batan Bingin, terdapat tinggalan arkeologi berupa 6 (enam) buah arca yang disimpan didalam banguan suci bernama Pelinggih Gedong Penyimpenan Agung. Keenam arca tersebut adalah 1 (satu) buah arca Bodhisattwa, 3 (tiga) buah arca jongkok, dan 2 (dua) buah arca Ganesa. Tinggalan arca di Pura Agung Batan Bingin sebelumnya pernah diteliti oleh I Made Kardana dari Universitas Warmadewa jurusan arkeologi tahun 1994 terkait arca bermuka gajah saja. Di sini penulis meneliti lebih lanjut terkait dengan arca Hindu-Buddha yang berada di Pura Agung Batan Bingin yaitu 1 (satu) buah arca Bdhisattwa dan 2 (dua) buah arca Ganesa. Penulis tertarik untuk membahas arca Hindu-Buddha di Pura Agung Batan Bingin, karena tulisan yang ada sebelumnya tidak menyentuh aspekaspek ikonografi yang dimiliki maupun fungsinya. Pokok permasalahan dari penelitiaan ini adalah: Bagaimana ciriciri ikonografi arca Hindu-Buddha di Pura Agung Batan Bingin Pejeng Kawan?, Apa fungsi arca Hindu-Buddha di Pura Agung Batan Bingin Pejeng 
Kawan?. Adapun tujuan dari penelitian ini adalah: Secara umum penelitian ini bertujuan untuk mengetahui keberadaan atau menggambarkan arca Hindu-Buddha di Pura Agung Batan Bingin Pejeng Kawan, sehingga upaya mengetahui nilai-nilai yang terkandung dalam arca tersebut diharapakan dapat menambah keyakinan untuk menjaga dan melestarikan tinggalan arca maupun nilainya (Rema, 2015). Untuk mengetahui ciri-ciri ikonografi arca Hindu-Buddha di Pura Agung Batan Bingin. Untuk mengetahui fungsi arca Hindu-Buddha di Pura Agung Batan Bingin.

\section{METODE}

Penelitian ini menggunakan tahapan yaitu tahap pengumpulan data dan tahap analisis data. Tahap pengumpulan data menggunakan cara observasi, studi pusatak dan wawancara tidak terstruktur. Tahap analisis menggunakan analisis kualitatif dan ikonografi (Suantika, 2013).

Analisis kualitatif juga menekankan pada deskritif, artinya dimana peneliti melakukan pencatatan secara teliti segala gejala atau fenomena yang dilihat, didengar dan dibaca melalui pengamatan, wawancara dan studi pustaka serta bentuk-bentuk seperti ungkapanungkapan atau kata-kata. Analisis ikonografi adalah suatu analisis yang digunakan untuk mengetahui identitas arca yaitu melakukan pemerian ciri-ciri ikonografi arca yang berkaitan dengan arca sebagai penggambaran tokoh tertentu seperti sikap tangan, kelengkapan arca, wahana, benda yang dibawa.

Penelitian ini menggunakan teori fungsional. Fungsi adalah kumpulan kegiatan yang ditujukan kearah pemenuhan kebutuhan tertentu atau kebutuhan system (Suwardika, 2017).Teori fungsional ini digunakan untuk menjawab permasalahan terkaitan dengan ciri-ciri ikonografi dan kegunaan atau fungsi dari arca Hindu-Buddha di Pura Agung

\section{HASIL DAN PEMBAHASAN}

\section{Gamabaran Umum Pura Agung Batan Bingin}

Pura Agung Batan Bingin terletak di

Desa Pejeng Kawan, Kecamatan Tampaksiring, Kabupaten Gianyar, Provinsi Bali. Pura Agung Batan Bingin letaknya sangat strategis, yaitu di tengahtengah desa adat (pakraman) Pejeng Kawan, tepatnya di banjar adat Tatiapi. Lokasi pura ini jaraknya sekitar $5 \mathrm{~km}$ dari kota Gianyar, $12 \mathrm{~km}$ dari kota kecamatan, $30 \mathrm{~km}$ dari kota Denpasar (Purnayasa, 2017). Situs pura ini dapat ditempuh melalui dua jalan, yaitu melalui Desa Pejeng Tengah kemudian menuju ke arah barat kurang lebih $2 \mathrm{~km}$. jalan lain menuju situs pura ini dapat juga ditempuh melalui Kecamatan Ubud kemudian kearah timur kurang lebih 2 $\mathrm{km}$. Kedua jalan ini cukup baik dapat dilalui kendaraan bermotor maupun mobil, hanya saja dari arah jalan Ubud terdapat tikungan yang menanjak dan cukup tajam.

Wilayah Desa Pejeng Kawan yang Memiliki luas wilayah 2,75 $\mathrm{km}^{2}$ Desa Pejeng Kawan terdiri atas enam Dusun/Banjar yaitu Banjar Tatiapi Kaja, Banjar Tatiapi Kelod, Banjar Dukuh Kangin, Banjar Dukuh Kawan, Banjar Dukuh Geria, Banjar Sala. Batas-batas wilayah Desa Pejeng Kawan, yaitu Sebelah utara Desa Pejeng Kaja, Sebelah selatan Desa Bedulu, Sebelah barat Desa Petulu, Sebelah timur Desa Pejeng.

Di Pura Agung Batan Bingin, didalamnya terdapat beberapa pura yaitu Pura Puseh, Pura Desa, Pura Batan Jepun, Pura Melanting, Pura Alas, Pura 
beji, dan Pura Dalem, untuk setiap pura diberi penjelasan masing-masing, terutama mengenai struktur dan fungsi palinggih disetiap mandala. Suatu hal yang perlu diingat adalah, bahwa Pura Agung Batan Bingin sebagai induk purapura lain yang ada disekitarnya, dengan struktur mandala dibagi menjadi tiga, yaitu utama mandala (jeroan), madya mandala (jaba tengah) dan nista mandala (jaba sisi). Bedasarkan rpengamatan dilapangan, kecuali Pura Alas, Pura Beji dan Pura Puseh, semua pura yang ada di kompleks Pura Agung Batan Bingin (Pura Batan Jepun, Pura Desa, Pura Melanting dan Pura Dalem), jaba tengahnya menjadi satu dengan Pura Agung Batan Bingin.

Di utama mandala (jeroan) terdapat beberapa banguan palinggih dan pura yang memiliki bentuk dan fungsi masingmasing. Berikut bentuk-bentuk palinggih dan fungsinya masing-masing. Palinggih Padmasana, Palinggih Gedong Tangkeb, Palinggih Ratu Lingsir, Panggih Gedong Pasimpenan Agung, Palinggih Pengaruman Agung, Bale Paselang, Bale Gong, Pahiasan Agung, Gedong Pasimpenan Ratu Alit, Panggungan, Pengaruman Ratu Alit, Pawedaan, Pura Desa/Bale Agung, Pura Puseh, dan Pura Batan Jepun.

Di Madya Mandala (jabe tengah) terdapat beberapa bangunan palinggih dan pura yang memiliki bentuk dan fungsi masing-masing. Bale Wantilan, Apit Lawang, Pura Melanting, dan Pura Dalem. Di nista mandala (jabe luar) terdapat dua buah bangunan wantilan tajen dan dua buah pura yang sangat berkaitan dengan Pura Agung Batan Bingin. Bale Wantilan Tajen, Pura Alas, Pura Beji, dan Bale Wantilan Tajen Baru.

\section{Ciri-Ciri Ikonografi Arca Hindu- Buddha di Pura Agung Batan Bingin}

Pura Agung Batan Bingin dapat dikatakan sebagai salah satu situs penting di Desa Pejeng, karena di pura tersebut ditemukan tinggalan arkeologi berupa arca Hindu-Buddha dan Arca Jongkok. Tinggalan arca di Pura Agung Batan Bingin terdiri atas 2 buah arca Ganesa, 1 buah arca Bodhisattwa, 3 Arca Jongkok. Dalam penelitian ini penulis mengkaji tiga buah arca yaitu arca-arca yang bercorak hindu Buddha. Dalam hal ini agar menjadi sistematis dalam penguraiannya, dikelompokan menjadi dua bagian, yaitu unsur non badaniah dan unsur badaniah. Unsur non-badaniah dalam penelitian ini meliputi hiasan dan perlengkapan arca seperti perhiasan berupa mahkota, perhiasan rambut, kalung (hara), ikat pinggang (mekhala), kelat bahu, gelang tangan (kankana), gelang siku, gelang lengan (keyura), gelang kaki (padanganda), tali perut (udarabhanda), tali kasta (upavita), kain, sampur, dan stela (Darma, 2019).

a. Mahkota (Makuta) dan Perhiasan Rambut (Mauli)

Arca yang mengunakan mahkota yaitu arca Bodhisattwa. Bentuk mahkota arca tersebut berbentuk jatamakuta. Mahkota yang digunakan berupa rambut bersusun, pada kiri dan kanan mahkota terdapat sepasang bunga yang kembang.

\section{b. Kalung (Hara)}

Hiasan kalung dikenakan oleh 1 arca yaitu arca Bodhisattwa. Pada bagian leher arca Bodhisattwa mengenakan kalung disebut hara berjumlah dua bermotif sulur dan bagian tengah melebar dan satu kalung bermotif manik-manik melingkar, mengenakan udarabandha bermotif sulur yang melebar

\section{c. Tali Kasta (Upavita)}

Pada kedua arca Ganesa terlihat mengenakan upavita yang menyilang dari bahu kiri sampai pinggang kanan, motif yang terdapat pada Ganesa I yaitu motif ukiran daun-daunan sedangkan arca Ganesa II motifnya tidak jelas karena aus. Pada arca Bodhisattwa 
mengenakan upavita yang terslempang dari bahu kiri sampai pinggang kanan, terdapat motif ukiran bulat-bulat.

\section{d. Tali Perut (Udarabhanda)}

Dari ketiga arca, hanya arca Bodhisattwa yang mengenakan udarabhanda dengan berhiasan ukiran berbentuk daun-daunan.

e. Gelang Lengan (Keyura), Gelang Tangan, Gelang Siku, dan Gelang Kaki

Pada bagian kedua pangkal lengan arca Ganesa I terdapat gelang lengan berbentuk melinggkar polos tanpa motif sedangkan arca Bodhisattwa mengenakan gelang kana bermotif simbar segi tiga.

Gelang tangan kedua arca Ganesa berbentuk bulat polos, sedangkan arca Bodhisattwa mengenakan gelang tangan bersusun tiga, dengan dua susun berbentuk genitri melingkar dan satu gelang bermotif simbar segi tiga.

Gelang siku hanya dikenakan oleh arca Bodhisattwa berupa gelang siku berbentuk bulat bermotif manik-manik.

Gelang kaki yang dikenakan dari kedua arca Ganesa berbentuk bulat polos, sedangkan gelang kaki yang dikenakan arca Bodhisattwa berupa gelang kaki berbentuk polos bersusun dua.

\section{f. Ikat Pinggang (Katisura)}

Ikat pinggang hanya dikenakan oleh kedua arca Ganesa, arca Ganesa I ikat pinggangnya berbentuk lingkaran sedikit ada goresan motif bunga, arca Ganesa II ikat pinggang yang dikenakan berbentuk lingkaran polos tanpa motif.

\section{g. Sampur (Urudama)}

Sampur hanya dikenakan kedua arca Ganes, sampur yang terdiri dari satu helai namun ditata sedemikian rupa sehingga membentuk lipatan-lipatan. Terlihat ada motif di dalamnya tetapi kurang jelas dikarenakan aus.

\section{h. Kain}

Kain yang dikenakan arca Ganesa I dan arca Ganesa II terlihat mengenakan kain menutupi pinggang sampai lutut, kain arca Ganesa I dengan hiasan motif bunga yang berisi kotak-kotak, arca Ganesa II dengan hiasan motif kotakkotak. Kain yang dikenakan arca Bodhisattwa, pada bagian bawah tergurat sampai lutut dan betis dan guratannya tampak jelas, samping diikat berbentuk ikatan pita dan ujung kain samping terjuntai sampai menempel pada stela. Sementara ujung kain depan sampai betis, kain tersebut polos tanpa motif.

\section{i. Lapik dan Stela}

Arca Ganesa I menggunakan lapik padma ganda berbentuk lingkaran. Arca Ganesa II dan arca Bodhisattwa lapik yang digunakan berbentuk segi empat, bermotif padma ganda.

Arca yang memakai stela antara lain arca Ganesa II dan arca Bodhisattwa. Bentuk dari stela arca Ganesa II diperkirakan berbentuk segi empat panjang, dikarenakan bagian atas stela aus . Bentuk dari stela arca Bodhisatwa berbentuk oval, dan nampak masih utuh pada bagian stela yang terdapat pada arca Bodhisattwa.

Unsur badaniah, hanya akan membicarakan beberapa komponen, terutama menyangkut tentang sikap tubuh, sikap tangan, sikap kaki, dan badan (Maulana, 1997). Ketiga arca Hindu-Buddha yang dijadikan objek penelitian menunjukkan sikap tubuh yang sama, kedua arca Ganesa dan arca Bodhisattwa dengan sikap duduk (asana).

Jumlah tangan dari kedua arca Ganesa bertangan empat tetapi tangan bagian belakang sudah patah. Kedua tangan arca Ganesa yang dimiliki saat ini dengan posisi tangan arca terletak di atas paha, dengan jari tangan terkepal. Arca Bodhisattwa memiliki dua tanagn. Sikap tangan dari arca Bodhisatwa dalam posisi 
telapak tangan kiri menengadah keatas, diletakan diatas pangkuan tepatnya dibelakang telapak kaki kanan dan diatas telapak tangan memegang bunga yang kembang, dan tangan kanan menengadah dan diletakan diatas paha kanan (wara mudra).

Sikap kaki Kedua arca Ganesha dengan sikap kaki wirasana yaitu dalam posisi kedua telapak kakinya menyatu di depan. Sikap kaki yang ditunjukan arca Bodhisattwa dalam posisi duduk bersila (padmasana) diatas lapik padma ganda, posisi kaki telapak kaki keduanya menghadap keatas. Apabila diperhatikan bahan yang digunakan, ketiga arca memakai batu tufa bersih yaitu batu padas dengan sedikit batu-batu kecil.

Berdasarkan atas ciri-ciri ikonografi yang dimiliki arca Hindu-Buddha di Pura Agung Batan Bingin, maka dapat diduga bahwa arca-arca tersebut termasuk ke dalam kelompok seni arca periodesasi Bali Kuna Abad X- XIII (Stutterheim, 1929).

\section{Fungsi Arca Hindu-Buddha di Pura} Agung Batan Bingin Pada Masa Lalu

Fungsi adalah hubungan antara suatu (pranata) dengan kebutuhan dari organisme sosial. Pandangan fungsional berusaha untuk mempelajari hubungan antara berbagai unsur, kecil maupun besar, dalam suatu kebudayaan, dimana hubungan tersebut berguna untuk membuat keseluruhannya berjalan (Sumerata, 2016). Konsep fungsi dalam sistem sosial dapat digunakan untuk mengkaitkan antara struktur sosial dengan proses kehidupan sosial, atau untuk mengkaitkan antara proses dengan struktur.

\section{a. Arca Ganesha}

Fungsi Ganesha pada masa lalu dilahirkan sebagai dewa penyelamat. Selain itu Ganesha juga dipercayai sebagai dewa penghalang rintangan, kebijaksanaan, dan ilmu pengetahuan
(Nugroho, 2017). Kepercayaan yang masih hidup dalam kehidupan masyarakat sekarang terhadap Ganesha merupakan kelanjutan dari kepercayaan kehidupan masyarakat di masa lampau (Bagus, 2015). Mengenai hal tersebut, fungsi arca Ganesha di Pura Agung Batan Bingin pada umumnya sama dengan fungsi Ganesha di masa lampau, vaitu sebagai penyelamat dan pelindung dari hal-hal yang bersifat jahat atau negatif.

\section{b. Arca Bodhisattwa}

Fungsi Bodhisattwa pada masa lalu sebagai penyelamat. Selain itu juga dipercayai sebagai maha pemberi anugrah kepada umatnya, kebijaksanaan, dan ilmu pengetahuan (Maulana, 1997). Kepercayaan yang masih hidup dalam kehidupan masyarakat sekarang terhadap arca Bodhisattwa merupakan kelanjutan dari kepercayaan kehidupan masyarakat di masa lampau. Mengenai hal tersebut, fungsi arca Bodhisattwa di Pura Agung Batan Bingin hampir sama dengan fungsi Ganesha yang sudah diuraikan diatas terlebih dahulu yaitu sebagai penyelamat, maha pemberi, kebijaksanaan dan ilmu pengetahuan.

\section{Fungsi Arca Hindu-Budha di Pura} Agung Batan Bingin Pada Masa Kini

Seperti halnya dengan peninggalan arca-arca lainnya, maka arca-arca HinduBuddha yang terdapat di Pura Agung Batan Bingin Desa Pejeng Kawan masih disakralkan oleh masyarakat Desa Pejeng Kawan hal ini terbukti dari arca-arca Hindu-Buddha yang disimpan dalam sebuah pelinggih yang bernama Gedong Pasimpenan Agung dan dipuja pada waktu upacara piodalan atau pun setiap harinya.

Arca-arca Hindu-Buddha yang terdapat di Pura Agung Batan Bingin peranannya masih cukup penting, yaitu berfungsi sebagai tempat untuk memohon kesehatan, keselamatan, dan 
kesejahteraan penyungsungnya, selain itu juga masih ada kaitannya dalam kehidupan masyarakat dewasa ini yang masih dipercayai memiliki kekuatan magis, yang dihubungkan dengan penolak wabah penyakit maupun kesuburan tanaman khususnya tanaman padi di Desa Pejeng Kawan. Maka dengan demikian dapat dikatakan bahwa kepercayaan terhadap arca yang terdapat di Pura Agung Batan Bingin masih tetap hidup dalam kehidupan masyarakat Desa Pejeng Kawan sampai saat ini yang merupakan kepercayaan dari masa lampau.

\section{SIMPULAN}

Berdasarkan hasil penelitian yang telah dipaparkan pada bagian sebelumnya, maka pada bagian akhir diurakan sebuah simpulan.Arca HinduBuddha di Pura Agung Batan Bingin menunjukan ciri-ciri ikonografi pada perhiasan, busana, dan sikap tubuh seperti sikap tangan, sikap kaki serta badan. Ciri-ciri ikonografi dikelompokan menjadi dua bagian, yaitu unsur non badaniah dan unsur badaniah. Dilihat dari gaya seni arca tersebut menunjukan karakter arca memperlihatkan gaya yang serba kaku dan kasar penyelesaiannya. Gaya seni arca ni dapat digolongkan pada gaya seni arca periode Bali Kuna Abad X- XIII. Fungsi Ganesha pada masa lalu dilahirkan sebagai dewa penyelamat. Arca Ganesha selain itu juga dipercayai sebagai dewa penghalang rintangan, kebijaksanaan, dan ilmu pengetahuan. Sedangkan fungsi arca Bodhsattwa dimasa lalu yaitu fungsi Bodhisattwa pada masa lalu sebagai penyelamat. selain itu juga dipercayai sebagai maha pemberi anugra kepada umatnya, kebijaksanaan, dan ilmu pengetahuan.
Arca-arca Hindu-Buddha yang terdapat di Pura Agung Batan Bingin peranannya masih cukup penting, yaitu berfungsi sebagai tempat untuk memohon kesehatan, keselamatan, dan kesejahteraan penyungsungnya, selain itu juga masih ada kaitannya dalam kehidupan masyarakat dewasa ini yang masih dipercayai memiliki kekuatan magis, yang dihubungkan dengan penolak wabah penyakit maupun kesuburan.

\section{REFERENSI}

Anggarini, $\quad$ Made Reisa.2017. "Perkembangan Bentuk Dan Fungsi Arca-Arca Leluhur Pada Tiga Pura Di Desa Keramas Blahbatuh Gianyar Suatu Kajian Etnoarkeolog". Jurnal Humanis, Fakultas Ilmu Budaya Unud Vol 18.2 Pebruari 2017

Arifin, Ferdi. 2015. "Representasi Simbol Candi Hindu Dalam Kehidupan Manusia: Kajian Linguistik Antropologis". Jurnal Penelitian Humaniora, Vol. 16, No. 2, Agustus 2015: 12-20.

Bagus, A. A. Gde. 2015. "Arca Ganesa Bertangan Delapan Belas di Pura Pingit Melamba Bunutin, Kintamani, Arkeologi, Volume 28, No. 1, April 2015

Darma, I Kadek Sudana Wira. 2019 "Pengarcaan Dewa Wisnu Pada Masa Hindu-Buddha Di Bali (Abad Vii-Xiv Masehi)". Forum Arkeologi Volume 32, Nomor 1, April 2019

Maulana, Ratnaesih. 1997. Gambaran Umum Ikonografi Siwa di India 
dari Sumber-sumber tertulis. Jakarta: Laporan Penelitian FSUL.

Nugroho, Hendro: Mandyartha, Eka Prakarsa. 2017. "Image Retrieval Arca Ganesha Dengan Menggunakan Metode Ekstrasi Fitur Moment Invariant Dan Tepi Deteksi Canny". Jurnal Ilmiah NERO Vol. 3, No.2, 2017

Prayudi, Putu Agus Weda: Redig, I Wayan: Jaya, Ida Bagus Sapta. 2016. "Tinggalan Arkeologi Di Pura Puseh Lan Bale Agung Tampuagan, Kecamatan Tembuku, Kabupaten Bangli”. Jurnal Humanis, Fakultas Ilmu Budaya Unud Vol 17. Desember 2016.

Purnayasa, Dewa Ngakan Putu. 2017 "Eksistensi Pura Agung Batan Bingin Desa Pakraman Pejeng Kecamatan Kabupaten Penelitian Kawan Tampaksiring Gianyar" Agama Hindu, Vol. 1 No 2 Oktober 2017.

Purwanto, Heri: Titasari, Coleta Palupi. 2018. "Arca Di Candi Cetho: Interpretasi Baru Sebagai Arca Panji". Jurnal Humanis, Fakultas Ilmu Budaya Unud Vol. 114 Mei 2018.

Putra, Putu Pradnyana Adi: Redig, I Wayan: Aryana, A. A. Gde. 2018. "Variasi Ikonografi ArcaPerwujudan Perunggu Koleksi Museum Bali Dan Arca BPCB Bali-Nusa Tenggara" Jurnal Humanis, Fakultas Ilmu Budaya Unud Vol 22.1 Pebruari 2018.

Stutterheim, W. F. t.t 1929. Oudheden Van Bali, Het Hijk Van Pejeng, Kirty Leif Kit-Van Der Tuuk Singaraja.
Suantika, I Wayan. 2013. "Arca Garuda Wisnu Di Pura Gelang Agung. Buangga Badung Volume 26, Nomor 1, April 2013.

Sumerata, I Wayan; Basudewa, Dewa Gede Yadhu. "Arca Bercorak Siwaistis di Kota Denpasar, Bali". 2016. Forum Arkeologi. Forum Arkeologi Vo 29 No 2, Agustus 2016.

Sunarya, I Nyoman. 2015. "Jejak-Jejak Peradaban kuno di Desa Getasan". Volume 28, Nomor 2, Agustus Kuno Di Desa Forum Arkeologi 2015.

Suwardika, I Made: Redig, I Wayan: Jaya, Ida Bagus Sapta. 2017. "Tinggalan Arkeologi di Pura Subak Bubunan Desa Sukawati, Sukawati, Kecamatan Kabupaten Gianyar". Jurnal Humanis, Fakultas Ilmu Budaya Unud Vol 18.1 Januari 2017.

Rema, Nyoman: Sunarya, Nyoman. 2015. "Lingga Berhias Padma Astadala". Volume 28, Nomor 2, Agustus 2015.

Rema, Nyoman. "Tradis Pemujaan Leluhur Pada Masyarakat Hindu di Bali" Forum Arkeologi, Volume 27, No. 1, April 2014. 